\title{
Cross-reactions between proteins isolated from new narrow-leafed lupine breeding lines and antibodies present in the sera of patients sensitized to soybeans and peanuts
}

\author{
Aneta Tomczak $^{1}$ - Magdalena Zielińska-Dawidziak ${ }^{1}$ - Dorota Piasecka-Kwiatkowska ${ }^{1} \cdot$ Ewa Springer $^{2}$. \\ Eleonora Lampart-Szczapa ${ }^{1}$
}

Received: 3 July 2018 / Revised: 21 September 2018 / Accepted: 29 September 2018 / Published online: 24 October 2018

(C) The Author(s) 2018

\begin{abstract}
Due to the observed increase of consumption of lupine-fortified food products and the high homology of lupine protein to other legumes, occurrence of new lupine allergy cases can increase significantly. Therefore, the aim of this study was to compare the seeds of 18 new Polish lupine breeding lines for immunoreactivity in relation to the sera of the patients sensitized to cross-reacting allergens, i.e. to soybeans and peanuts, using the western blot method. Antibodies present in the sera obtained from two adult outpatients cross-reacted with the studied extracts and made it possible to indicate six lines with decreased expression of Lup an 1 (high molecular weight subunit of $\beta$-conglutin): Mandelup, Mirela, Puławski Różowy Wczesny, Ignis, 25-65-M-4-1 and Stadoliszczenskij L-610 lines. Two more lines (Schmalblaettrige Schwerzplatzen and Rammiespielyj) are probably also less immunoreactive, due to the decreased content of alkaline subunit of $\alpha$-conglutin — Lup an 2 . The highest variability in immunoreactivity of proteins in question was noted for peptides with molecular weights $\sim 20,23,28,33,38,39$, $43,49,50$ and $63 \mathrm{kDa}$. Unfortunately, different patterns of immunoreactivity of the seeds obtained from various cultivation sites was noted for some lines. The correlation between the total protein content and reduced immunoreactivity of the tested lines was not confirmed. Thus, the lines with decreased immunoreactivity could be considered material for future crossing the narrow-leafed lupine lines to obtain varieties intended for food production.
\end{abstract}

Keywords Cross-reactivity $\cdot$ Lupine $\cdot$ Pea nuts $\cdot$ Soybean $\cdot$ Western blot analysis

\section{Introduction}

Magdalena Zielińska-Dawidziak

mzd@up.poznan.pl

Aneta Tomczak

aneta.tomczak@up.poznan.pl

Dorota Piasecka-Kwiatkowska

dorota.piasecka-kwiatkowska@up.poznan.pl

Eleonora Lampart-Szczapa

eleonora.lampart-szczapa291@up.poznan.pl

1 Department of Biochemistry and Food Analysis, Poznan University of Life Sciences, ul. Mazowiecka 48, 60-623 Poznan, Poland

2 Center for Allergy Diagnostics and Treatment SNOZ Alergologia Plus, Poznan, Poland
Three Lupinus species have been used in food technology, mainly because of their excellent functional properties and high nutritional value [28]. Lupine's little cultivation requirements mean that it can grow in any climate, which means that its cultivation is an attractive option [24]. Currently, the amount of food produced in Europe with the addition of sweet lupines is consistently increasing [7]. Due to their valuable amino acid composition, lupine seeds are used to produce nutrients for athletes, food for people suffering from celiac disease, and is a potential substitute for soy protein [20, 27, 31,35]. Lupine flour is found in various slimming products, as it is rich in fiber and low in fat, and has the lowest glycemic index among legumes [10]. Lupine seed components have a clinically proven therapeutic effect, demonstrating an anti-diabetic and anti-metabolic syndrome effect $[1,35]$. It has been indicated that replacing animal 
proteins by lupine ones prevents the development of cardiovascular disease.

However, as lupine consumption increased, immunoreactivity of its protein was noted [10]. Therefore, the European Commission has introduced lupine on the list of food allergens [28]. Furthermore, not only the food or inhalation allergies have been noted, but also the cross-reactivity effects of peanut, soy and lupine proteins [22]. Lupine proteins are closely related to soybean and peanut ones, so it is not surprising that humans may suffer from an allergy to Lupinus species, while soybean and peanut have been well-known allergens for a long time. Peanut and soy allergens are well recognized, because they have been considered the two most dangerous ones, which may even lead to anaphylactic shock and, as a consequence, to death [7]. The strongly allergenic fractions of peanut (Ara ha 1) and soy (Gly $\mathrm{m}$ 5) show $47 \%$ and $54 \%$ homology to the lupine protein fraction- $\beta$-conglutin (from the vicilin family), the only one lupine allergen included on the allergen list [10, 12-14]. Literature data show that $44-50 \%$ of people allergic to peanuts are also allergic to narrow-leafed lupine [23, 24].

Thus, the aim of this study was to analyze immunoreactivity of the new lupine lines, on the basis of cross-reactivity between the proteins isolated from narrow-leafed lupine and antibodies secreted in the sera collected from the people sensitized to peanut and soy proteins.

\section{Materials and methods}

\section{Materials}

Blue lupine (Lupinus angustifolius) seeds of 18 sweet breeding lines (Table 1) were obtained from two places of cultivation (Przebędowo and Wiatrowo), from the year of harvesting 2015. Cultivation conditions were the same in both places of breeding; however, weather conditions were different, because of the cultivation locations [data presented by Tomczak et al. [30]. The soybean seeds (Augusta variety) were purchased from the Department of Genetics and Plant Breeding (Poznan University of Life Sciences), while the peanuts were obtained from commercial points. The seeds have been ground and not degreased.

\section{Patients}

Two adult outpatients with detailed history of oral allergy of the SNOZ Alergologia Plus Center for Diagnosis and Treatment of Allergy Therapy in Poznań (Poland) were donors of the sera used in the investigations. These patients showed strong allergic symptoms to peanut; both were allergic to soybean, but the patient who was a donor of serum No 1 was
Table 1 Blue lupine lines selected for the studies and the total protein content in the seed

\begin{tabular}{|c|c|c|c|}
\hline \multicolumn{2}{|c|}{ Lines of blue lupine } & \multicolumn{2}{|c|}{$\begin{array}{l}\text { Protein content ( } \% \text { of dry } \\
\text { matter) }\end{array}$} \\
\hline No. & Name of the line & Przebędowo & Wiatrowo \\
\hline 1 & Mandelup & $34.81 \pm 0.3 r^{*}$ & $32.03 \pm 0.1 \mathrm{~h}, \mathrm{i}$ \\
\hline 2 & Vitabor & $33.22 \pm 0.21, \mathrm{~m}$ & $33.43 \pm 0.1 \mathrm{~m}, \mathrm{n}$ \\
\hline 3 & No-730 & $32.82 \pm 0.2 \mathrm{k}$ & $30.75 \pm 0.01$ \\
\hline 4 & New from Spain & $31.67 \pm 0.2 \mathrm{~g}, \mathrm{~h}$ & $38.24 \pm 0.0 \mathrm{w}$ \\
\hline 5 & Mirela & $34.59 \pm 0.1 \mathrm{p}, \mathrm{r}$ & $32.51 \pm 0.1 \mathrm{j}$ \\
\hline 6 & Puławski Różowy Wczesny & $36.74 \pm 0.1 \mathrm{t}$ & $32.98 \pm 0.1 \mathrm{k}, 1$ \\
\hline 7 & Ignis & $36.94 \pm 0.1 \mathrm{t}$ & $37.38 \pm 0.2 \mathrm{u}$ \\
\hline 8 & 25-65-M-4-I & $35.89 \pm 0.2 \mathrm{~s}$ & $34.00 \pm 0.0 \mathrm{o}$ \\
\hline 9 & Stadoliszczienskij L-610 & $31.84 \pm 0.0 \mathrm{~g}, \mathrm{~h}$ & $31.47 \pm 0.1 \mathrm{f}$ \\
\hline 10 & Silena & $27.87 \pm 0.3 \mathrm{a}$ & $34.37 \pm 0.2 p$ \\
\hline 11 & Haagena & $35.72 \pm 0.0 \mathrm{~s}$ & $31.18 \pm 0.1 \mathrm{e}$ \\
\hline 12 & Sur & $32.18 \pm 0.2 \mathrm{i}$ & $32.99 \pm 0.1 \mathrm{k}, 1$ \\
\hline 13 & Bordako & $32.55 \pm 0.2 \mathrm{j}$ & $29.64 \pm 0.0 b$ \\
\hline 14 & Borlu & $31.23 \pm 0.3 \mathrm{e}$ & $32.07 \pm 0.0 \mathrm{~h}, \mathrm{i}$ \\
\hline 15 & $\begin{array}{l}\text { Schmalblaettrige Schwer- } \\
\text { zplatzen }\end{array}$ & $32.91 \pm 0.0 \mathrm{k}$ & $33.56 \pm 0.0 \mathrm{n}$ \\
\hline 16 & Population-1 & $30.52 \pm 0.1 \mathrm{c}$ & $31.15 \pm 0.1 \mathrm{e}$ \\
\hline 17 & WTD-1406 & $34.58 \pm 0.0 \mathrm{p}, \mathrm{r}$ & $35.68 \pm 0.1 \mathrm{~s}$ \\
\hline 18 & Ranniespielyj & $33.95 \pm 0.10$ & $29.54 \pm 0.1 b$ \\
\hline
\end{tabular}

*Values denoted by different letters differ statistically significantly at the significance level $\alpha=0.05$

less allergic than the other one. The method used to determine the antibody class was the ELISA test. The obtained serum characteristic is presented in Table 2. Bioethical Commission at the Poznan University of Medical Sciences (Poland) accepted the application for permission to carry out these tests (No 671/17, 2017).

\section{Methods}

\section{Protein content determination}

\section{Kjeldahl method}

Total protein content was determined in the ground, not degreased seeds, by means of the Kjeldahl method [FAO 2003]. Nitrogen content was recalculated into protein content with the conversion factors 6.25 . 
Table 2 Used sera characteristics

\begin{tabular}{|c|c|c|c|c|}
\hline \multirow[b]{3}{*}{ Serum } & \multicolumn{4}{|c|}{ Allergy to } \\
\hline & \multicolumn{2}{|c|}{ Soy bean } & \multicolumn{2}{|c|}{ Peanut } \\
\hline & Class & $\begin{array}{l}\text { IgE concentra- } \\
\text { tion }(\mathrm{kU} / \mathrm{L})\end{array}$ & Class & $\begin{array}{l}\text { IgE con- } \\
\text { centration } \\
(\mathrm{kU} / \mathrm{L})\end{array}$ \\
\hline I & 4 & $\sim 50$ & 4.5 & 50-100 \\
\hline II & 2 & $0.7-3.5$ & 6 & $>100$ \\
\hline
\end{tabular}

\section{Bradford method}

The concentration of protein in the extracts obtained from the seeds was determined according to the Bradford method (1976). The analyses were carried out at wavelength $\lambda=595 \mathrm{~nm}$ using UV-Vis spectrophotometer SP 8001, Metertech Inc. Taipei, Taiwan.

\section{Protein extraction}

Proteins from the ground seeds were extracted with a PBS (ratio $1: 10 \mathrm{w} / \mathrm{v}$ ). The samples were mixed in $4^{\circ} \mathrm{C}$ for $17 \mathrm{~h}$, then centrifuged $(15,000 \times g, 30 \mathrm{~min})$ and frozen in $-20^{\circ} \mathrm{C}$.

\section{SDS-PAGE}

The abundance of different proteins in the obtained extracts was examined using $14 \%$ polyacrylamide gel electrophoresis under denaturing conditions [16], in samples containing $7 \mu \mathrm{g}$ of protein and molecular marker among $20-120 \mathrm{kDa}$ (Thermo Scientific, 26612). The gels were stained with Coomassie Brilliant Blue and documented using CLIQS (TotalLab Quant, Great Britain).

\section{IgE immunobloting}

Proteins separated with SDS-PAGE electrophoresis were transferred to polyvinylidene difluoride membrane (Immobilon-P $0.45 \mu \mathrm{m}$, Merck Millipore Ltd.). Next, the membranes were blocked with $0.01 \mathrm{~mol} / \mathrm{L} \mathrm{TBS,} \mathrm{pH} \mathrm{7.4,} \mathrm{con-}$ taining 1\% BSA (Sigma A7906, USA) for $1 \mathrm{~h}$. The sera diluted in $1 \%$ solution of BSA in TBS-Tween (1:20 vol/vol) were applied for overnight incubation in $4{ }^{\circ} \mathrm{C}$. After fivefold washing, membranes were incubated for $1.5 \mathrm{~h}$ with monoclonal anti-human IgE antibody marked with phosphatase alkaline (SIGMA A3076, USA), diluted 1:1000 with blocking buffer containing additionally $0.05 \%$ Tween 20 (SIGMA P9416, USA). Membranes were washed five times and then the substrate was applied for $20 \mathrm{~min}$. As a substrate, BCIP/ NBT (5-bromo-4-chloro-3'-indolyphosphate and nitro-blue tetrazolium) was used (Calbiochem, USA). The reaction was stopped with water and the membranes were dried and analyzed with the CLIQSprogram (TotalLab Quant, Great Britain).

\section{Results and discussion}

\section{Protein concentration}

Lupinus angustifolius contains $42 \%$ of protein [34], mainly globulins and albumins. The average protein content determined by the Kjeldahl method in the studied seeds from the Przebędowo cultivation place was $33.3 \% \pm 2.3$, while in Wiatrowo it was $32.9 \% \pm 2.4$ (Table 1). Thus, the noted differences were not statistically significant when the average protein content from various cultivation places were compared. However, the differences among the lines were visible: Silena from Przebędowo contained only $27.87 \pm 0.3 \%$ of protein in dry matter, while Ignis from the same cultivation place contained $36.94 \pm 0.3 \%$. The lowest content of protein in the seeds from Wiatrowo was determined for Ranniespielyj [29.54 $\pm 0.1 \%$ dry matter (d.m.)], while the highest for New from Spain (38.24 $\pm 0.0 \%$ d.m.). Such huge differences are not uncommon and are usually a consequence of precipitation in the maturation time [25, 29, 33].

Globulins are important proteins of lupine seeds and they include mainly $\beta$-conglutin (43.4\%, from vicilin like-protein family), $\alpha$-conglutin (family of legumin like-proteins, 33\%) $\delta$-conglutin $(12.5 \%)$ and $\gamma$-conglutin $(6 \%)$ [8, 10, 23]. They are usually indicated as the most immunoreactive proteins for patients with food allergy to lupine proteins. To extract them from the studied material, the buffer recommended by Howard [11] and Peeters [23] was used. This buffer allowed to separate globulins which include main lupine, soybean and peanut allergens. The average determined concentration of protein in the obtained extract was $5.8 \mathrm{mg} / \mathrm{ml}$ (from Przebędowo seeds) and $6.2 \mathrm{mg} / \mathrm{ml}$ (from Wiatrowo seeds). It means that the applied buffer allowed for the extraction of $19.2 \pm 0.4 \%$ of total proteins from Przebędowo seeds and $20.5 \pm 0.4 \%$ from Wiatrowo ones.

\section{SDS-PAGE electrophoresis}

Abundance and diversity of proteins extracted from the analysed seeds were studied by SDS-PAGE electrophoresis, and are presented in Fig. 1. According to Parisot [21], the most important immunoreactive fractions of narrowleaved lupines are peptides with the molecular weight in range $17-79 \mathrm{kDa}$. There were $14-15$ peptide fractions separated by SDS-PAGE electrophoresis in the interesting molecular mass range, i.e. $18-88 \mathrm{kDa}$, in the studied extracts from lupine seeds. The significant differences of the peptide profile in the range typical for HMW (high molecular weight), subunit of $\beta$-conglutin, were not noted. 
(a) Przebędowo
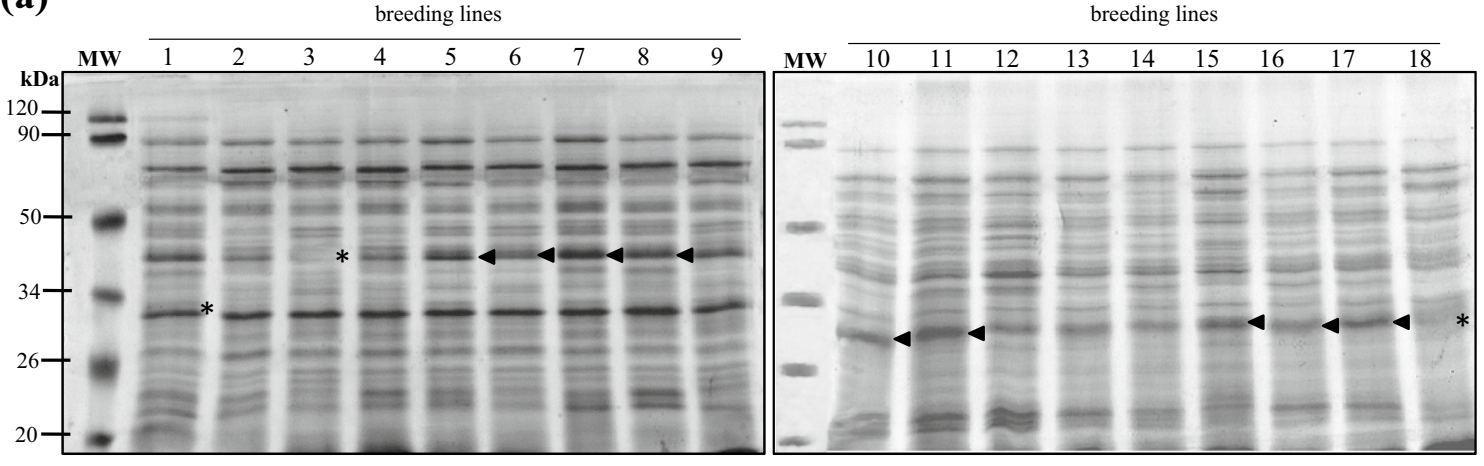

(b)
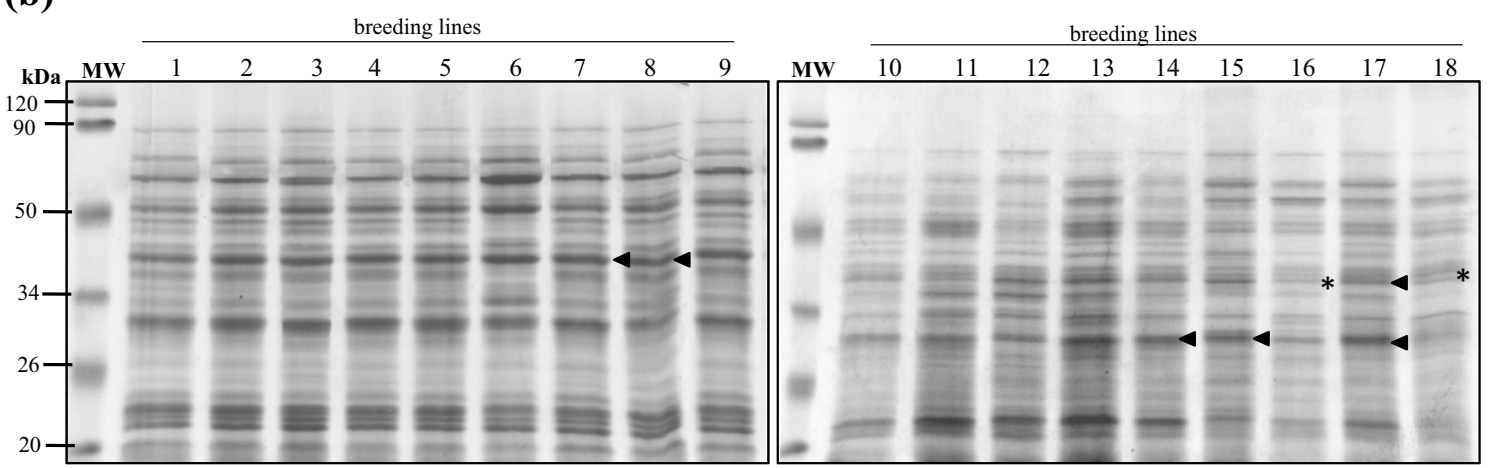

(c)

Positive controls

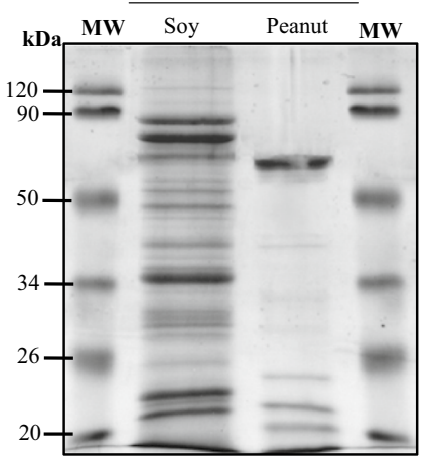

Fig. 1 SDS-PAGE separations profiles with Coomassie blue staining: $\mathbf{a}$ breeding lines of blue lupine from Przebędowo; $\mathbf{b}$ breeding lines of blue lupine from Wiatrowo; c positive controls: soybean (Angus) and

Because it is the only allergenic lupine fraction approved by WHO/IUIS (World Health Organisation \& International Union of Immunological Societes) (2017), the differences in the expression of those peptides should strongly influence the immunoreactivity of the extracts. However, as the densytometric analysis indicate, significantly lowered than average content of the peptide with $\mathrm{MW} \sim 43 \mathrm{kDa}$ was found in the extract obtained from the line 3 (No 730) cultivated in Przebędowo. Compared to the lines 5-8 (Mirela, Puławski Różowy Wczesny, Ignis and 25-65-M-4-I), the peanut. $M W$ molecular weight marker. The arrowhead (asterisk) indicate less, while asterisk (filled pointed arrow) more expressed fractions

intensity of the band from line 3 was almost three times decreased. While the extracts from Wiatrowo lines 7 (Ignis) and 8 (25-65-M-4-I) and 17 (WTD-1406) were richer in that fraction, the lines16 (Population-1) and 18 (Rammiespielyj) were poorer in it (Fig. 1). According to Guillamón et al. [10], the fraction $\sim 43 \mathrm{kDa}$ can be acidic subunits of $\alpha$-conglutin or $\beta$-conglutin subunits with an Intermediate Molecular Weight (IMW), known as immunoreactive fractions of lupine proteins [23]. Some differences in the peptides composition were also noted for 


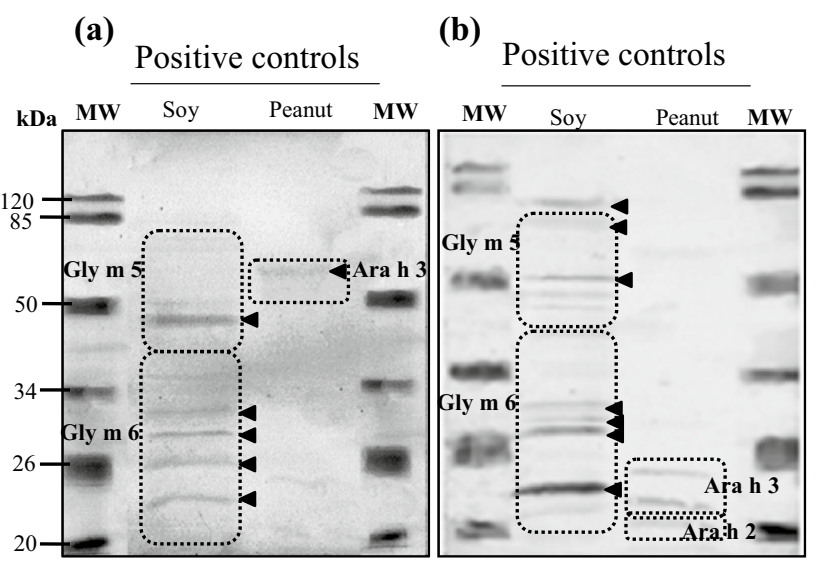

Fig. 2 Images of membrane obtained as a result of immunoblotting of protein extracted from positive controls (soy and peanut) with a serum I; b serum II. $M W$ molecular weight marker

another peptide from the range typical for IMW subunit of $\beta$-conglutin-peptide with MW $\sim 31 \mathrm{kDa}$. The higher intensity of this band was observed for the lines 10-11 (Silena and Haagena) and 15-17 (Schmalblaettrige Schwerzplatzen, Population-1, WTD-1406) from Przebędowo and 14, 15 and 17 from Wiatrowo; while the lowest one was observed for the lines 1 and 18 (Mendelup, Rammiespielyj) from Przebędowo.

Since the differences in the profiles of the extracted peptides were not confirmed for the same lines cultivated in both the places, it can be suggested that, unfortunately, this is not a consequence of the genetic variability of the studied lines, but only of the response to variable weather conditions and seeds maturity.

SDS-PAGE analysis of soy extract, prepared in the applied conditions, allowed for the detection of 20 peptides with MW in the range $21-84 \mathrm{kDa}$ (Fig. 1a, b), while in the extract obtained from peanut, only of 9 peptides with MW among 19-60 kDa (Fig. $1 \mathrm{c}$ ) were visualized. Peanut extract that is poor in protein fractions should not come as a surprise. The peanut that is rich in protein $(\sim 26 \%)$ contains $87 \%$ of globulins, most of them being only two proteins: arachin (MW $\sim 21 \mathrm{kDa}$ ) and conarachin (MW $65 \mathrm{kDa}$ ) [2]. These extracts from soybean and peanut were applied in the further analysis as a positive control to analyze the peptides immunoreactivity with the antibodies present in the used sera.

\section{IgE immunoblotting}

Immunoblots were performed on lupine (18 breeding lines), soybean and peanut extracts. All studied samples were tested using two sera (I, II), and obtained immunoblotting images were analyzed. Figure 2 shows the results obtained for soybean and peanut extract, which constitute the positive controls in the presented studies.
Using serum I, obtained from the patient with strong allergenicity to peanut and moderate one to soy proteins, reactivity of the antibodies to five soybean peptides (with MW20 kDa-48 kDa) and only one peptide with MW $\sim 57 \mathrm{kDa}$ from the peanut extract was confirmed. Currently, IUIS have accepted six proteins as soybean allergens (Gly m 3-Gly m 8) [12-14].

Gly $\mathrm{m} 6$ is a hexameric protein assembled by five different subunits, G1 (53.6 kDa), G2 (52.4 kDa), G3 (52.2 kDa), G4 (61.2 kDa) and G5 (55.4 kDa) [32]. These individual subunits are found both as heterodimeric peptide linked by a disulfide bridge composed of chains $20-40 \mathrm{kDa}$ plus $10-25 \mathrm{kDa}$, and simultaneously as intact precursor proteins $(50-60 \mathrm{kDa})$ [32]. The strongest reactivity against the soy extract protein with the serum I was noted to the fraction with $\mathrm{MW} \sim 49 \mathrm{kDa}$ (50\% total intensity in the line determined in densytometric analysis), which suggests that it can be that intact precursor. Moreover, the reactivity to peptides with the MW in the range $22-30 \mathrm{kDa}$ was observed. This indicated that this patient probably showed a strong immunoreactivity to Gly m 6 (Fig. 2a).

Three peanut proteins from among the 17 included on the WHO/IUIS list are recognized as a strong allergen: Ara $\mathrm{h} 1$ (65 kDa), Ara h $2(\sim 18$ and $20 \mathrm{kDa})$ and Ara h $3(60 \mathrm{kDa})$ $[5,7]$. The presented immunoblotting result indicated that the patient I was allergic to Ara h 3 (fraction $60 \mathrm{kDa}$ on Fig. 2a). This heterodimeric protein consists of a series of polypeptides with $\mathrm{MW} \sim 20$ to $\sim 45 \mathrm{kDa}$, which can be classified as acidic and basic subunits, resulting from the modification by post-translational cleavage $[3,15]$. The results are consistent with the literature data which suggest immunoglobulins cross-reactivity Ara h 3 and Gly $m 6$ [4, 5]; thus, the antibodies secreted with the serum I reacted with these two allergens: Gly $\mathrm{m} 6$ and Ara h 3 .

The images of membranes presenting the reactivity of serum II against the extracts from the positive control samples and the molecular weights of the individual protein fractions are shown in Fig. 2b. Antibodies present in serum II reacted with 11 soy protein fractions with MW among 21 and $78 \mathrm{kDa}$. The $22 \mathrm{kDa}$ fraction had a $37 \%$ share in intensity of bands in the line, and four others fractions $(\sim 27, \sim 28$, $\sim 30, \sim 49 \mathrm{kDa}$ ) from the range typical for an allergenic soybean fraction Gly $m$, reacted with this serum [19]. What was also proved was the immunoreactivity of the patient II antibodies with the protein in the range typical for the patient allergic to soy conglicynin (band with MW $\sim 67 \mathrm{kDa}$ ). Gly m 5 is an alpha subunit of beta-conglycinin of soy, which is a trimer protein, composed of subunits $\alpha(67 \mathrm{kDa}), \alpha^{\prime}(71 \mathrm{kDa})$ and $\beta(50 \mathrm{kDa})$ [18].

Three fractions with molecular weights from 20 to $23 \mathrm{kDa}$ were detected in the peanut extract. The fractions closest to the $20 \mathrm{kDa}$ could be the fractions of Ara h 2, which together account for the majority of the effector the activity 
(a)

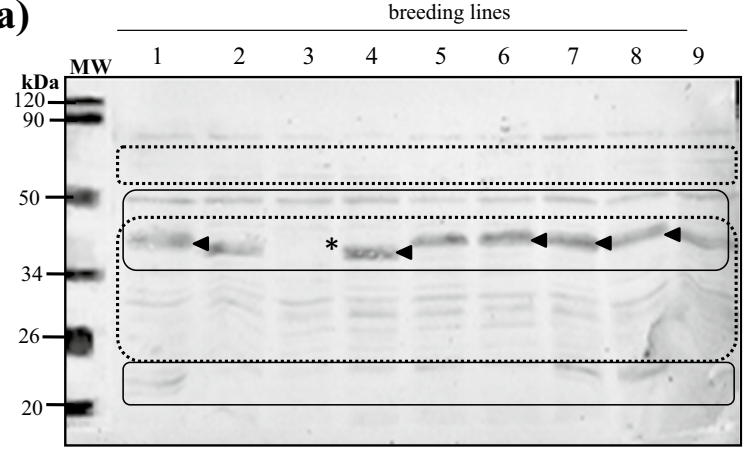

(b)

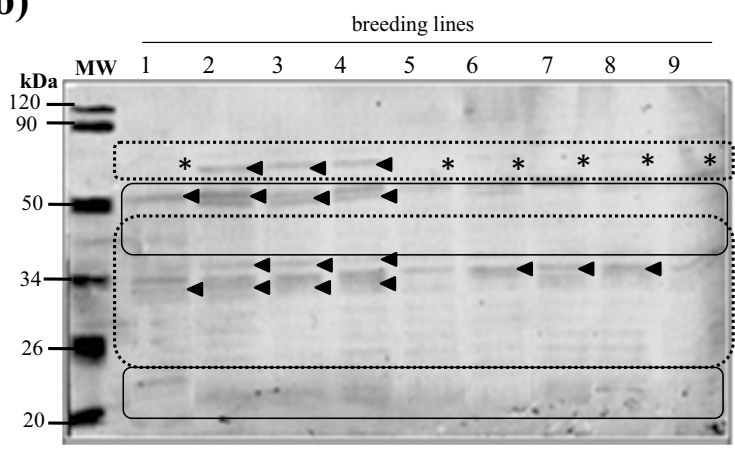

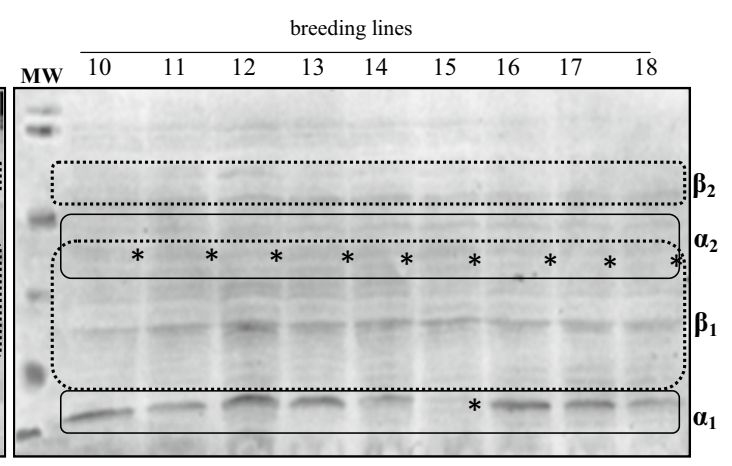

Fig. 3 Membranes obtained after immunoblotting of extracts form breeding lines of blue lupine from Przebędowo: a serum I; b serum II. $M W$ molecular weight marker. Conglutin fractions$\alpha_{1}$ : $\alpha$-conglutin basic subunit $(20-22 \mathrm{kDa}), \alpha_{2}: \alpha$-conglutin acidic subunit $(42-52 \mathrm{kDa}), \beta_{1}$ : $\beta$-conglutin IMW subunit $(25-46 \mathrm{kDa})$,

of the whole peanut extract [26]. There are few literature data about cross-reactivity of Ara h 2 and other allergens [5]. However, monosensitization to Ara h 2 is rare, usually polysensitization with Ara h 1 and/or Ara h 3 is observed [5]. On the presented membranes, the subunits of Ara h 3 could also be detected - peptides with a molecular weight in the range 14-45 kDa, i.e. $\sim 22$ and $\sim 23 \mathrm{kDa}[3,15]$.

Summing up, the reactivity of the used sera differed significantly, which is very valuable for the study of variability in immunoreactivity of the lupine breeding lines tested.

Only one lupine protein is registered as a lupine food allergen in the Allergen Nomenclature (International Union of Immunological Societes and WHO): $\beta$-conglutin (as Lup an 1; fractions with the molecular weight 55-61 kDa). However, the immunoreactivity of many fractions of lupine proteins has been confirmed; there is $\beta-, \alpha-$, and $\gamma$-conglutin among them [9]. Unfortunately, these proteins are storage globulins, therefore, usually at the time of crossing lines, the aim is to increase their content in seeds. Moreover, they are polymeric proteins, with a different pattern of hydrolysis during maturation [9]. On the basis of the confirmed crossreactivity between Ara h 3, Gly m 6 and $\alpha$-conglutin, as well Ara h 1, Gly m 5 and $\beta$-conglutin [4-6], these two immunoreactive fractions of lupine seeds were detected, excluding

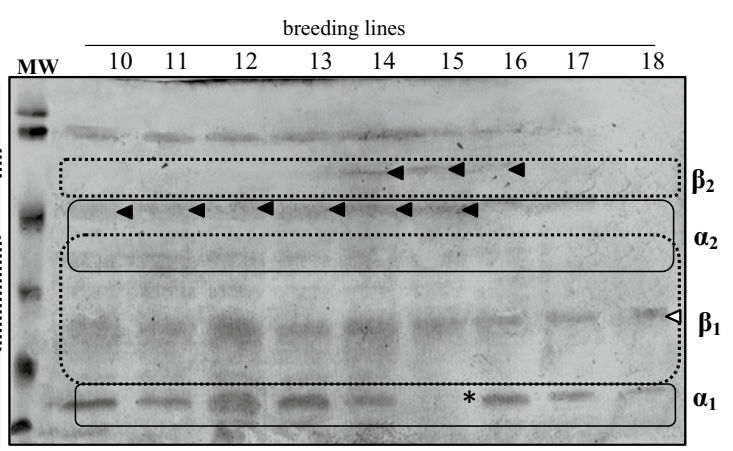

$\beta_{2}$ : $\beta$-conglutin HMW subunit (53-64 kDa).The arrowhead (asterisk) indicate less, while black asterisk (filled pointed arrow) more expressed; white asterisk (open pointed arrow) fractions identified in each line in the blot

$\gamma$-conglutin, because $\gamma$-conglutin is usually considered a less immunoreactive fraction, and accounts for only $\sim 4-5 \%$ of total proteins.

While the extracts from the lines cultivated in Przebędowo were studied, the antibodies present in serum I reacted with the peptides with molecular range typical for $\alpha$-conglutin subunits (Fig. 3a). In the range typical for $\alpha$-conglutin acidic subunit (42-52 kDa), each studied extract contained a peptide with MW $\sim 9 \mathrm{kDa}$. However, significant differences were noted, especially for the peptide $\sim 43 \mathrm{kDa}$, whose highest content was present in the lines 1, 4, 6-8 and not observed in the lines 3 and 10-18. Significant differences are noted also for the other - basic $\alpha$-conglutin subunit. One peptide from that range was immunoreactive in the lines $1,4,5,7,8,10-14$ and 16-18, while the other extract did not contain this peptide. Summarizing, the lines which were significantly less immunoractive to the antibodies present in the serum I, were the lines 3 and 15 (No-730 and Schmalblaettrige Schwerzplatzen). The immunoreactivity was consistent with the literature suggestions. Based on the reactions observed with positive controls, it was found that the serum contained the antibodies directed against Gly m 6 and Ara h 3, while the cross-reactivity of these proteins and lupine $\alpha$-conglutin was confirmed [17]. 


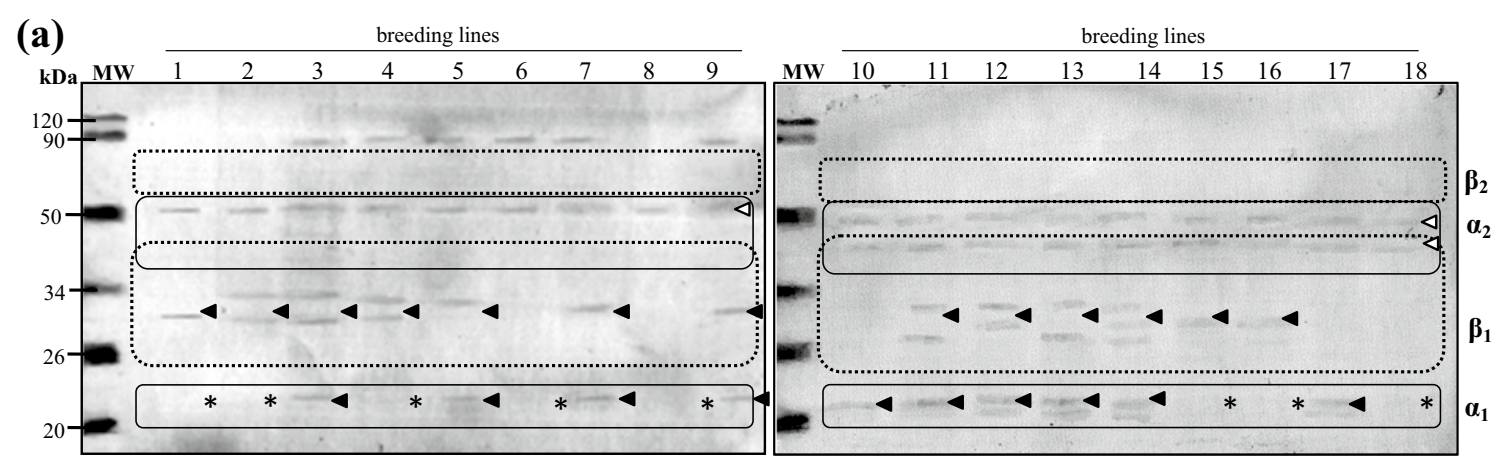

(b)
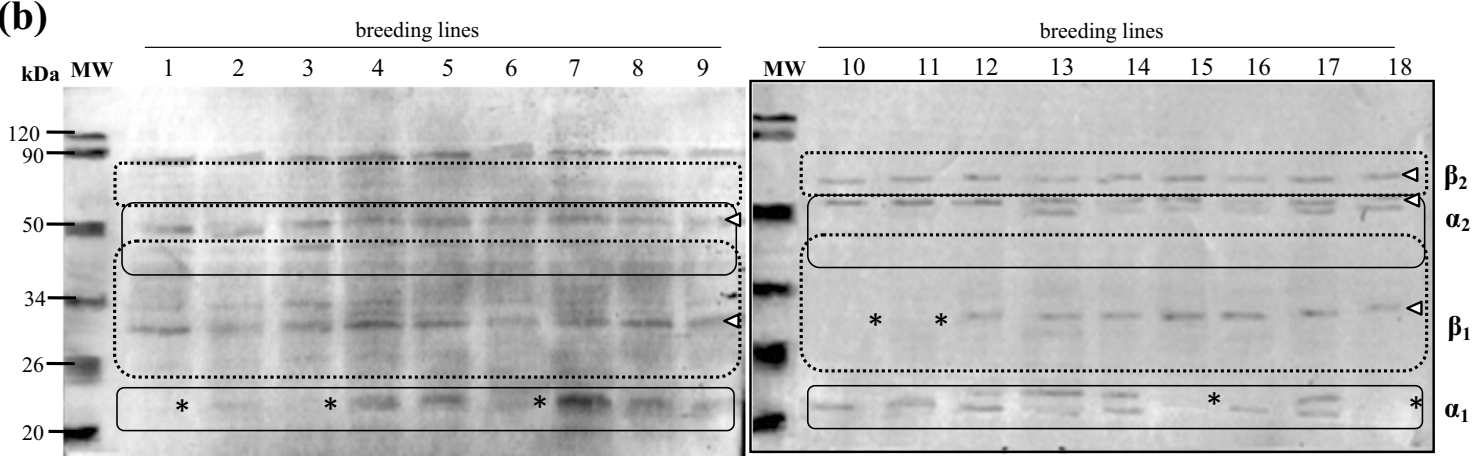

Fig. 4 Membranes after immunoblotting breeding lines of blue lupine from Wiatrowo: a serum I; b serum II. $M W$ molecular weight marker. $\alpha_{1}: \alpha$-conglutin basic subunit $(20-22 \mathrm{kDa}), \alpha_{2}: \alpha$-conglutin acidic subunit (42-52 kDa), $\beta_{1}$ : $\beta$-conglutin IMW subunit (25-46 kDa), $\beta_{2}$ :

Different immunoreactivity was noted when the serum II was applied (Fig. 3b). The serum contained antibodies anti-Gly $\mathrm{m} 6$ and anti-Gly $\mathrm{m} 5$, as well as anti-Ara $\mathrm{h} 2$ and anti-Ara $\mathrm{h} 3$. These antibodies cross-react not only with $\alpha-$, but also with $\beta$-conglutin. In the range typical for HMW of $\beta$-conglutin (53-64 kDa), the reactivity of peptide $\sim 62 \mathrm{kDa}$ was noted for the lines $2-4$ and $14-16$. It should be emphasized again, that HMW of $\beta$-conglutin is the only one allergen included on the WHO/IUIS list as Lup an 1. However, the immunoreavtivity of $\beta$-conglutin IMW subunit was also observed: for peptide $\sim 39 \mathrm{kDa}$ (lines $6-8$ ), $\sim 38 \mathrm{kDa}$ (lines $2-4$ ), $\sim 33 \mathrm{kDa}$ (lines 1-4) and $\sim 28 \mathrm{kDa}$ (lines 10-18). These observations confirmed the previously noted crossreactivity between Gly m 5, Ara h 1 and $\beta$-conglutin [6], which points to possible allergenicity of the studied seeds in the case of the people allergic to soybean and peanut. The differences were also significant when anti-Gly m 6 antibodies from that serum reacted with $\alpha$-conglutin subunits. Immunoreative peptide or two peptides with $\mathrm{MW} \sim 50 \mathrm{kDa}$ were detected in extract from 1 to 4 and 10-15, indicating the presence of $\alpha$-conglutin acidic subunit. Moreover, the only line where the presence of $\alpha$-conglutin basic subunit was not confirmed was the line 15 (Schmalblaettrige Schwerzplatzen), for which the reactivity of peptides with MW $\sim 23 \mathrm{kDa}$ was not observed (Fig. 3b). $\beta$-conglutin HMW subunit (53-64 kDa).The arrowhead (asterisk) indicate less, while asterisk (filled pointed arrow) more expressed fractions, white asterisk (open pointed arrow) fractions identificed in each line in the blot

Because of the declared and confirmed allergenicity of Lup an 1 (i.e. HMW subunit of $\beta$-conglutin), the particularly interesting lines seemed to be the lines 1 , and 5-9, cultivated in Przebędowo, which did not contain the peptide from that range (Mandelup, Mirela, Puławski Różowy Wczesny, Ignis, 25-65-M-4-I, Stadoliszczienskij L-610). Also the line15 (Schmalblaettrige Schwerzplatzen) seemed to be less immunoreactive and interesting from the point of view of nutrition. The line could be poorer in the basic subunit of $\alpha$-conglutin.

Next, the extract obtained from the same lines cultivated in the second place-Wiatrowo-were studied. The immunoreactivity of these extracts differed significantly from those obtained before, even if the general trends are constant. Thus, the serum I (Fig. 4a) not recognized fraction of Lup an 1 (HMW fraction of $\beta$-conglutin) in the studied lines, because its antibodies were directed anti-Gly $\mathrm{m} 6$ and Ara $h 3$. Surprisingly, they recognized some (1-3) fractions of IMW $\beta$-conglutin in the lines $1-5,7,9,11-16$, with MW $31-33 \mathrm{kDa}$, but the clinical effects of this reactivity could be not observed. What could be clinically significant, due to the confirmed cross-reactivity and the class of the used serum, was the interaction with the varied $\alpha$-conglutin fractions. The peptide with the $\mathrm{MW} \sim 51 \mathrm{kDa}$ was detected in each studied extract, and in extracts from the lines 10-18, also the 
peptide $\sim 49 \mathrm{kDa}$ was observed. This confirms the reactivity of the serum with the $\alpha$-conglutin acidic subunit. However, the most important reactivity with the basic subunit was also noted: in the lines $3,5,7,9,10-14$ and 17 , the peptides ( 1 or 2 ) in the range $22-23 \mathrm{kDa}$, which is typical for $\alpha$-conglutin basic subunit (Lup an 2 allergen).

Densytometric analysis of the membranes after incubation with the second serum (Fig. 4b) through cross-reactivity antibodies against Gly $\mathrm{m} 5$ and Lup an 1, allowed for the identification of $\beta$-conglutin HMW fractions presence in the lines10-18 (the peptide $\sim 62 \mathrm{kDa}$ ). A completely different pattern of the reactivity with IMW $\beta$-conglutin was also observed. The dominating immunoreactivity in that range was noted for the peptide with $\mathrm{MW} \sim 31 \mathrm{kDa}$ (not observed in the lines 10-11). The fractions within the range $~ 32$ to $33 \mathrm{kDa}$ were also reactive. The antibodies of that serum also confirmed the immunoreactivity of $\alpha$-conglutin subunits. Peptide $\sim 51 \mathrm{kDa}$ or doublet of peptides, i.e. 49 and $51 \mathrm{kDa}$ were detected in each line, thus the presence of acidic $\alpha$-conglutin subunits was found. However, what is more interesting in terms of immunoreactivity, is the detection of the basic subunit in this conglutin (i.e. the peptides in the range $20-22 \mathrm{kDa}$ ), which was observed in the lines $1,3,6,15$ and 18 .

Among the same lines obtained from the second cultivation places (Wiatrowo), some less immunoreactive lines should be indicated. Among them, there is mainly line 1 (Mandelup) in which neither $\beta$-conglutin HMW subunit nor $\alpha$-conglutin basic subunit was detected. This result, however, is not consistent with that noted for the same line cultivated in Przebędowo, which may indicate different maturation of the seeds obtained from two different cultivation places [9].

Lines 1, 5-9 (Mandelup, Mirela, Puławski Różowy Wczesny, Ignis, 25-65-M-4-1 and Stadoliszczenskij L-610) seemed to be poorer in HMW subunits of $\beta$-conglutin, and consequently, in the Lup an 1 allergen fractions, in both cultivation places. Crossing these lines may be an interesting method aiming at decreasing the content of that allergen. However, it should be remembered that the alkaline subunit of $\alpha$-conglutin lupine is considered one of the major lupine allergens (Lup an 2), even if it is currently not included on the WHO allergens list due to the fact that its significance in clinical studies has not been confirmed [10]. In that situation, line 15 (Schmalblaettrige Schwerzplatzen) and 18 (Rammiespielyj) which were poorer in that fraction, may be also interesting for future cultivation studies.

\section{Conclusions}

Introducing lupine seeds into various products must be declared by the producer on the label because of the confirmed allergenicity of lupine. Simultaneously, the increasing level of lupine consumption induces the reported incidence of lupine allergy [23]. Immunoreactivity of the lupine seeds globulins in the case of the persons allergic to soy and peanut was confirmed in the presented studies for each studied extract.With application of the studied sera, the lines: Mandelup, Mirela, Puławski Różowy Wczesny, Ignis, 25-65-M-4-1 and Stadoliszczenskij L-610 seemed to contain decreased content of this allergenic fraction. Moreover, the noted immunoreactivity was more differentiated than the one noted before with the application of children sera [30]. The most important would be to indicate lines with decreased expression of $\beta$-conglutin, especially HMW subunit which is confirmed allergen, included on the WHO list. However, the presence of the alkaline subunit of lupine $\alpha$-conglutin, considered one of the major lupine immunoreactive proteins (Lup an 2), is also important. Thus, also the line Schmalblaettrige Schwerzplatzen and Rammiespielyj can be considered less immunoreative in future studies. It is worth emphasizing that the reduced reactivity of the fraction of Lup an 1 in these lines was not a consequence of their lowered content of the total protein (it is marked in the Table 1), even if the most immunorective proteins-seeds globulines-are the storage lupine proteins. It should be expected that weather conditions, and - as a consequence - maturity of the seeds influenced the presented results. Therefore, the studies should be extended and furthermore, their results should be confirmed with the larger number of sera. Applying other patients' sera may change the results, because the profile of the secreted antibodies is an individual matter. Thus, the discussed studies should be taken into account as the indication for further works on crossing the narrow-leafed lupine lines intended for nutritional purposes. They showed that crossing lines may lead to obtain new, sweet breeding lines with differentiated immunoreactivity. It may be important to ensure the higher safety of the food produced with the addition of lupine seeds and may reduce the appearance of new allergy cases.

Acknowledgements The presented results were obtained within the PBS3/A8/28/2015 project SEGENMAS http://www.segenmas.pl/.

\section{Compliance with ethical standards}

Conflict of interest Aneta Tomczak, Magdalena Zielińska-Dawidziak, Dorota Piasecka-Kwiatkowska, Ewa Springer, Eleonora Lampart-Szczapa declare that they have no conflict of interest.

Compliance with ethics requirements Bioethical Commission at the Poznan University of Medical Sciences (Poland) positively considered the application for permission to carry out these tests (No 671/17, 2017), which guarantees compliance with the required ethical standards.

Open Access This article is distributed under the terms of the Creative Commons Attribution 4.0 International License (http://creativeco 
mmons.org/licenses/by/4.0/), which permits unrestricted use, distribution, and reproduction in any medium, provided you give appropriate credit to the original author(s) and the source, provide a link to the Creative Commons license, and indicate if changes were made.

\section{References}

1. Alvarez J, Guillamón E, Crespo JF, Cuadrado C, Burbano C, Rodríguez J, Fernández C, Muzquiz M (2005) Effects of extrusion, boiling, autoclaving, and microwave heating on lupine allergenicity. J Agric Food Chem 4:1294-1298

2. Arya SS, Salve AR, Chauhan S (2006) Peanuts as functional food: a review. J Food Sci Technol 53:31-41

3. Barre A, Jacquet G, Sordet C, Culerrier R, Rouge P (2007) Homology modelling and conformational analysis of IgE-binding epitopes of Ara h 3 and other legumin allergens with a cupin fold from tree nuts. Mol Immunol 44:3243-3255

4. Blankestijn MA, Knulst AC, Knol EF, Thuy-My L, Rockmann H, Otten HG, Klemans RJ (2017) Sensitization to PR-10 proteins is indicative of distinctive sensitization patterns in adults with a suspected food allergy. Clin Transl Allergy 7:42-51

5. Bublin M, Breiteneder H (2014) Cross-reactivity of peanut allergens. Curr Allergy Asthma Rep 4:426-451

6. Chruszcz M, Maleki SJ, Majorek KA, Demas M, Bublin M, Solberg R, Hurlburt BK, Ruan S, Mattisohn ChP, Breiteneder H, Minor W (2011) Structural and immunologic characterization of Ara h 1, a major peanut allergen. J Biol Chem 45:39318-39327

7. Holden L, Lindvik H, Faeste CK (2009) Immunoglobulin E crossreactivity between lupine conglutins and peanut allergens in serum of lupine-allergic individuals. J Investig Allergol Clin Immunol 4:283-291

8. Duranti M, Restani P, Poniatowska M, Cerletti P (1981) The seed globulins of Lupinus albus. Phytochemistry 20:2071-2075

9. Duranti M, Consonni A, Mangi C, Sessa F, Scarafoni A (2008) The major protein of lupin seeds: characterization and molecular properties for use and functional and nutraceutical ingredients. Food Sci Technol 19:624-633

10. Guillamón E, Rodríguez J, Burbano C, Muzquiz M, Pedrosa MM, Cabanillas B, Crespo JF, Sancho AI, Mills EN, Cuadrado C (2010) Characterization of lupin major allergens (Lupinus albus L.). Mol Nutr Food Res 11:1668-1676

11. Howard A (2006) Master's degree project. Characterisation of allergenic components in soya bean. UPTEC X 06:06-09

12. Thermo Scientific (2018). http://www.phadia.com/da/Products/ Allergy-testing-products/ImmunoCAP-Allergen-Information/ Food-of-Plant-Origin/Allergen-Components/rAra-h-1/. Accessed 23 Oct 2018

13. International Union of Immunological Societes and WHO (2017). http://www.allergen.org. Accessed 23 Oct 2018

14. International Union of Immunological Societies (IUIS) Allergen Nomenclature Sub-Committee (2017). http://www.allergen.org/ Allergen.aspx. Accessed 23 Oct 2018

15. Koppelman SJ, Knol EF, Vlooswijk RA, Wensing M, Knulst AC, Hefle SL, Gruppen H, Piersma S (2003) Peanut allergen Ara h 3: isolation from peanuts and biochemical characterization. Allergy 11:1144-1151

16. Laemmli UK (1970) Cleavage of structural proteins during the assembly of the head of bacteriophage T4. Nature 5259:680-685

17. Magni C, Ballabio C, Restani P, Sironi E, Scarafoni A, Poiesi C, Duranti M (2005) Two-dimensional electrophoresis and westernblotting analyses with anti Ara h 3 basic subunit IgG evidence the cross-reacting polypeptides of Arachis hypogaea, Glycine max, and Lupinus albus seed proteomes. J Argic Food Chem 6:2275-2281

18. Maruyama N, Katsube T, Wada Y, Oh MH, Barba De LaRosa AP, Okuda E, Nakagawa S, Utsumi S (1998) The roles of the N-linked glycans and extension domains of soybean $\beta$-conglycinin in folding, assembly and structural features. Eur J Biochem 258:854-862

19. Mittag D, Vieths S, Vogel L, Becker WM, Rihs HP, Helbling A, Wüthrich B, Ballmer-Weber BK (2004) Soybean allergy in patients allergic to birch pollen: clinical investigation and molecular characterization of allergens. J Allergy Clin Immunol $1: 148-154$

20. Naruszewicz M (2005) White lupin protein to prevent cardiovascular disease: clinical evidence. In: Arnoldi A (ed) Final conference of healthy-profood, 9-18 November, Milan, pp 169-171

21. Novembre E, Moriondo M, Bernardini R, Azzari C, Rossi ME, Vierucci A (1999) Lupin allergy in a child. J Allergy Clin Immunol 6:1214-1216

22. Parisot L, Aparicio C, Moneret-Vautrin DA, Guerin L (2001) Allergy to lupine flour. Allergy 9:918-919

23. Pawankar R, Bunnag C, Khaltaev N, Bousquet J (2012) Allergic rhinitis and its impact on asthma in Asia pacific and the ARIA. World Allergy Organ J 3:212-217

24. Peeters KA, Nordlee JA, Penninks AH, Chen L, Goodman RE, Bruijnzeel-Koomen M, Hefle SL, Taylor SL (2007) Lupine allergy: not simply cross-reactivity with peanut or soy. J Allergy Clin Immunol 3:647-653

25. Peeters KA, Koppelman SJ, Penninks AH, Lebens A, BruijnzeelKoomen CA, Hefle SL, Taylor SL, van Hoffen E, Knulst AC (2009) Clinical relevance of sensitization to lupine in peanutsensitized adults. Allergy 4:549-555

26. Podleśny J, Podleśna A (2011) Effect of rainfall amount and distribution on growth, development and yields of determinate and indeterminate cultivars of blue lupin. Pol J Agron 4:16-22

27. Porterfield HS, Murray KS, Schlichting DG, Chen X, Hansen KC, Duncan MW, Dreskin SC (2009) Effector activity of peanut allergens: a critical role for Ara h 2, Ara h 6, and their variants. Clin Exp Allergy 39:1099-1108

28. Singh B, Bhat TK, Singh B (2003) Potential therapeutic applications of some antinutritional plant secondary metabolites. J Agric Food Chem 51:5579-5597

29. Svobodova M, Mairal T, Nadal P, Bermundo MC, O'Sullivan CK (2014) Ultrasensitive aptamer based detection of $\beta$-conglutin food allergen. Food Chem 15:419-423

30. Tomczak A, Zielińska-Dawidziak M, Piasecka-Kwiatkowska D, Lampart-Szczapa E (2018) Blue lupine seeds protein content and amino acids composition. Plant Soil Environ 64:147-155

31. Tomczak A, Zielińska-Dawidziak M, Piasecka-Kwiatkowska D, Springer E (2018) Prozdrowotne właściwości żywności aspekty żywieniowe i technologiczne. In: Karwowska M, Jackowska I (eds) Towarzystwo Wydawnictw Naukowych "Libropolis" (in Polish, English abstract)

32. Troszyńska A, Honke J, Kozłowska H (2001) Naturalne substancje nie odżywcze (NSN) pochodzenia roślinnego jako składniki żywności funkcjonalnej. Postępy Fitoterapii 2:17-22

33. Wang F, Robotham JM, Teuber SS, Sathe SK, Roux KH (2003) Ana o 2, a major cashew (Anacardium occidentale L.) nut allergen of the legumin family. Int Arch Allergy Immunol 132:27-39

34. Zielińska-Dawidziak M, Nawracała J, Piasecka-Kwiatkowska D, Król E, Staniek H, Krejpcio Z (2012) The impact of the year of soybean (Glycine $\max$ L. Merrill) harvest on the accumulation of iron from $\mathrm{FeSO}_{4}$ solutions. Fragm Agron 29:183-193

35. Zielińska-Dawidziak M, Lampart-Szczapa E (2017) Czy łubin może stać się polską soją? Przemysł spożywczy 1:39-41 (in Polish) 